\title{
TRADE LIBERALIZATION AND ECONOMIC GROWTH: A PANEL DATA ANALYSIS FOR TRANSITION ECONOMIES IN EUROPE
}

\author{
DOI: 10.17261/Pressacademia.2019.1047 \\ JEFA- V.6-ISS.2-2019(3)-p.82-94
}

\section{Kemal Erkisi ${ }^{1}$, Turgay Ceyhan ${ }^{2}$}

${ }^{1}$ Istanbul Gelisim University, Department of International Trade, Avcılar, Istanbul, Turkey. kerkisi@gelisim.edu.tr, ORCID: 0000-0001-7197-8768

2 Istanbul Gelisim University, Department of Economics and Finance, Avcılar, Istanbul, Turkey. tceyhan@gelisim.edu.tr, ORCID: 0000-0001-5225-297X

Date Received: March 23, 2019

Date Accepted: June 18, 2019

To cite this document

Erkisi, K., Ceyhan, T. (2019). Trade liberalization and economic growth: a panel data analysis for transition economies in Europe. Journal of Economics, Finance and Accounting (JEFA), V.6(2), p.82-94,

Permemant link to this document: $\underline{\text { http://doi.org/10.17261/Pressacademia.2019.1047 }}$

Copyright: Published by PressAcademia and limited licenced re-use rights only.

\section{ABSTRACT}

Purpose- In this study, the long-term and the short-term relationships between economic growth and trade liberalization for 13 transition countries in Europe were examined.

Methodology- The dataset includes 303 observations from 1995 to 2016 for the variables of gross domestic product (GDP), export (EXP), import (IMP), gross fixed capital formation (GFCF), foreign direct investment (FDI) and human capital (HC). PLS Test, Pesaran (2004) CD-Test, Pesaran (2007) Unit Root Test, Swamy S Homogeneity Test conducted before causality and cointegration analysis. Dumitrescu \& Hurlin (2012) Granger Panel Causality Test for short-term causality, and Westerlund ECM Panel Cointegration and PDOLS Estimator for long-term relationships analyses were employed.

Findings- The short-term outcomes revealed that there is a bidirectional causality between (a) EXP and GDP, (b) GFCF and GDP, (c) FDI and GDP, (d) HC and GDP, and a unidirectional causality (e) from IMP to GDP. The long-term results show that (i) a $1 \%$ raise in EXP boosts GDP by $0.39 \%$, (ii) a $1 \%$ raise in IMP boosts GDP by $0.11 \%$ (iii) a $1 \%$ raise in GFCF boosts GDP by $0.37 \%$ (iv) a $1 \%$ raise in FDI reduces GDP by $1.35 \%$, (v) a $1 \%$ raise in $\mathrm{HC}$ boosts GDP by $0.54 \%$ in the long-term.

Conclusion- Both in the short-term and the long-term trade liberalization has a positive impact on economic growth in mutual way between EXP, IMP and GDP as it is argued by the feed-back hypothesis.

Keywords: Economic Growth, Trade Liberalization, Export, Import, Panel Data Analysis JEL Codes: 047, 040, E21

\section{INTRODUCTION}

Trade liberalization reflects the degree of freedom of trade policies implemented by countries in the process of trade relations with the rest of the world (Saçık, 2009: 280). Trade openness, a channel in which goods and services, foreign direct investments and capital inflows move across borders or to certain countries and regions, is the basis of economic growth for developing countries (Özcan et al., 2018: 62).

The view that trade liberalization affects economic growth goes back to Adam Smith (Majeed, 2010: 204). This concept has been the subject of intense debate up to the present day, starting with the basic views of economists such as Hume, Smith and Ricardo, who advocated the School of Mercantilism and Classical Economics. Trade liberalization, which has come to the fore frequently after the crisis period in the 1970s and the structural economic transformation of neo-liberal policies proposed in the 1980s, can bring economic effects according to the competitiveness of the countries and the market shares of the exporting countries (Yapraklı, 2007: 68).

The comparative advantages created by trade openness provide the optimum distribution of resources and increase income level by improving the division of labor and specialization in the economy (Türedi and Berber, 2010: 303). The idea that Classical Economics put forward in the 18th and 19th centuries, that free trade increases economic efficiency and thus growth by encouraging international specialization, began to be reshaped in the later periods in line with the arguments developed 
for and against it. However in the theoretical framework; from theory to practice, the notions that emphasize the advantages of openness began to be more clearly seen in Singapore, Taiwan, South Korea and Hong Kong, the countries of Southeast Asia in the early 1960s, and widely in many developing countries in the 1970s and 1980s (Medina-Smith, 2001: 2). The orthodox economic policies, implemented in these years where significant structural economic transformations took place, have adopted the target of integrating the world economies by shifting the aggregate demand from the domestic market to the foreign market within the scope of export-oriented growth strategies. Thus, the emphasis on foreign trade in the direction of orthodox stabilization programs has been the most basic goal since 1990s (Emsen and Değer, 2007: 162).

Removal of restrictions on trade in goods and services encourages growth by enabling countries to produce and export commodities that they specialize in (Ümit, 2016: 256). The foreign exchange obtained from the increase in exports provided with trade liberalization helps to increase the national income level by increasing the imports of raw materials and intermediate goods which cannot be produced within the country. Free trade enables the development of new technologies and production techniques in accordance with the demand for the goods of foreign countries, resulting in an increase in total factor productivity and thus increased production, employment and consumption. Moreover, it increases the efficiency in production by positive externalities created by providing information dissemination among countries (Yapraklı, 2007: 69).

International trade and capital movements which increase with globalization allows the economies to be more integrated with each other. In some cases; trade liberalization, which is the dynamics of growth for emerging economies, may adversely affect the macroeconomic indicators of countries or cause crises. Especially in countries that cannot turn free trade into advantages, as trade liberalization increases, the country's imports are increasing and foreign trade deficits are seen. In addition, the increase in the dependence of the countries that have started to be opened to the world economy on the other countries may cause the country's economy to be exposed to the economic fluctuations in the global markets. In order to eliminate these negative impacts in the economy, countries should perceive trade openness as a mechanism that can increase the level of domestic production and should take economic measures to minimize potential risks arising from the foreign market (Çeliköz et al., 2017: 105).

In general, it should be noted that trade openness positively affects the growth rates of countries. In this context, many countries are trying to liberalize their economies by removing trade barriers. With the acceleration of globalization, the importance of protectionist policies is gradually decreasing and free market economy policies come to the fore. Although trade liberalization has positive and negative effects in the present, it can be said that it benefits all countries in the longterm.

In the study, following the introduction, foreign trade theories are discussed and their views and assumptions about trade liberalisation and economic growth are explained. In addition, it is mentioned through which channels trade liberalisation affects growth. After giving a summary of the literature about the subject, econometric tests are used to examine the relationship between the variables and the results of the analysis are evaluated.

\section{THEORETICAL FRAMEWORK}

Foreign trade provides various benefits to countries in many ways. Firstly; trade increases the efficiency of distribution of world resources by equalizing the values of goods and services. Secondly, the trade enables countries to specialize in the areas where they are comparatively most effective (in the production of goods and services) and in this way to obtain earnings. Finally, trade offers consumers a number of benefits from more efficient production techniques. Large-scale production of goods and services with small market volumes is not economically profitable. However, goods and services can be offered to consumers at cheaper prices as large-scale production reduces costs (Tupy, 2005: 2).

Free trade can lead to growth, in case a foreign trade policy is implemented in which the national economies can be integrated with the international structure and the resources allocated for production are directed to the sectors determined by foreign demand. Therefore, the dynamism required to achieve industrialization and growth is actualised by foreign demand rather than domestic demand (Mercan and Göçer, 2014: 28).

The mercantilist view that prevailed in the 16th and 17th centuries, argued that only the exporting country would benefit from the trade between two countries. Today, however, this opinion has lost its validity and it is accepted that static and dynamic gains from trade are obtained. Adam Smith explains the view with the Theory of Absolute Advantage that trade will increase growth and prosperity in two countries in the long-term (Saçık, 2009: 280). According to Smith, free foreign trade in a country with specialization and division of labor increases the efficiency of produced goods and services and efficiency in resource allocation. The effectiveness of domestic producers in foreign competition increases with their emphasis on R\&D and technology investments, which increases product range and quality. All these developments contribute to the welfare of the countries and the growth of their economies (Mercan and Göçer, 2014: 30).

David Ricardo who developed "Comparative Advantages Theory" upon A. Smith's theory; under the assumptions of full employment and perfect competition, provided that the international price ratio of the goods is between the rates of 
domestic opportunity costs, suggests that countries may acquire welfare gains from trade by specializing in the goods they produce with the lowest opportunity cost and by exporting the overproduction on domestic demand and importing the goods from other countries that they can produce relatively expensive. These gains arising from the trade increases, resulting from the transfer of resources from one sector to another sector with increasing specialization are called "static gains" according to comparative advantages. These gains which create prosperity in trade are characterized as "static", because they are the result of a one-time acquisition and removal of tariff barriers and no more resources for redistribution (Saçık, 2009: 281).

Dynamic trade gains contain positive effects of trade that contribute to economic development and growth. Such gains consist of gains from trade that consistently benefit. These are countervailing of output gap and resources, market creation for domestic surplus, creating a large market volume that allows to take advantage of economies of scale, increasing competition, development of domestic market demand and creating economic dynamism (Saçık, 2009: 281). Moreover, trade can indirectly promote economic development through other channels such as technology transfer, product variety and efficient allocation and distribution of resources. However, in cases where the technology and capital accumulation of trading partners are considerably different from each other, economic integration might have negative effects on countries even if it increases growth rates worldwide (Özcan et al., 2018: 62).

The Heckscher-Ohlin-Samuelson model, a theory which suggests that trade is an economic activity that makes both sides profitable, analyzes the welfare gains of two countries as a result of trade openness. The basic proposition of the model in the context of international trade is that trade will allow the redistribution of economic resources between sectors, each country to export the commodity for which it uses a relatively cheap and abundant factor in production, and import the commodity produced by using the relatively scarce and expensive factor. The Heckscher-Ohlin-Samuelson model is important in that trade liberalization is an important policy for raising real wages and promoting economic growth in developing countries (Özcan et al., 2018: 62).

In economic growth models, the results of the relationship between foreign trade and economic growth are not clear and precise. The Harrod-Domar Model, which is one of the contemporary growth theories and the only capital as the production factor, propound that trade liberalization positively affects economic growth. However, this is only possible if the marginal efficiency of capital is positive. The Neo-Classic Growth Model, also known as the Solow Model, was built on the assumption of a closed economy in the 1950s. In the model, it is assumed that technological changes are exogenous and there is no foreign trade (Özcan et al., 2018: 62).

Economists such as Krueger (1978), Balassa (1985), Singer and Gray (1988), and Greenaway and Sapsford (1994), who contributed a bit more to Neo-Classical Economics, established models that emphasized export-based growth and suggested that increase in export has a positive impact on real GDP growth. In the export-oriented growth strategy, the neo-classical supply-side growth model which represents openness reveals the association between total factor productivity and economic growth. The Neo-Classical Growth Model is the most commonly expressed by the Cobb-Douglas type production function. By adding the export variable to this function, the increase in total factor productivity can be determined (Emsen and Değer, 2007: 163-164).

There are also some studies focusing on the demand side of economic growth. These studies addressing economic growth in the context of demand are Keynesian-based. In this respect, the growth model that Kaldor (1970) builds on Hicks' growth model stands out (Emsen and Değer, 2007: 164). Kaldor (1970), taking into account the demand size of economic growth, says that the main constraint of economic growth in open economies is foreign demand. It is suggested in the hypothesis that the increase in autonomous demand driven by the long-term growth rate is at the center of the growth, and thus export or foreign demand in the open industrialized economies has a key importance in growth (Federici and Marconi, 2002: 323).

The dynamic gains obtained as a result of opening to international trade constitute the main elements of the endogenous growth theories led by Romer (1986) and Lucas (1988). In endogenous growth models, it is possible to establish long-term relations between trade liberalization and economic growth. It is stated in the model that in parallel with the liberalization of imports, advanced capital goods will encourage technology transfer through imports. High levels of foreign capital inflows and growing export revenues increase the import of technology intensive capital goods (Özcan et al., 2018: 62). At this point, R\&D activities are becoming important. Import is an important channel for reaching new information and technologies developed in the world and contributes to long-term growth (Korkmaz and Aydın, 2015: 52). In addition, open economies can benefit from technological fluctuations that encourage trade, which can lead to economic growth (Özcan et al., 2018: 62).

Endogenous growth models deal with the relation between liberal trade and growth in terms of comparative advantage. The contribution of trade to economic growth may change, depending on whether the power of comparative advantage may lead economic resources to long-term growth-producing activities or move away from such activities. In addition, the aforementioned theories point out to financial and technological constraints in less developed countries and say that these countries may be deprived of social capability required to adopt technologies produced in developed economies. Thus, the effect of trade on economic growth may vary according to the level of economic development (Zahonogo, 2016: 42). 
It should be noted that trade encourages growth in many ways. In order to increase the growth rates, it is important to make the resource allocation in the country effectively. The fact that countries specialize and produce in areas where they have relative cost advantages over other countries increases foreign trade earnings and growth. This leads to an increase in productivity by enabling countries to use more labor and capital in sectors where they gain high earnings in foreign markets.

Trade is expanding the markets by attracting domestic manufacturers. Domestic producers can profit from foreign trade by performing their production at the most efficient scale and lowering their costs. Trade leads to dissemination of new ideas and technologies which increases the productivity of labor and employers. Also, technology transfers through trade are of particular importance for developing countries that use underdeveloped technologies and do not have enough capacity to produce new technologies. The removal of trade barriers (taxes on imports, import quotas, etc.) increases the purchasing power and living standards of consumers by allowing them to access cheaper products. Free trade also allows companies to purchase cheap inputs, resulting in lower production costs and increased competitiveness (Majeed, 2010: 204).

Foreign companies entering the market with foreign trade may cause the profits of existing domestic firms to fall. It is possible for domestic firms to contribute to financial development and economic growth by using new technologies, focusing on new investments and developing new production techniques against the risk of decreasing their profits in the competition environment. In this context, trade liberalization can lead firms to innovate, and this tendency can enable to economic growth by increasing output level and quality (Çeliköz et al., 2017: 106-107).

The increase in international trade enables the expansion of technology and knowledge through the direct import of hightech products, thus contributing economic growth. Trade facilitates economic integration through innovations and increases acquisitions from foreign direct investments. Trade openness expand the market and allow production under the conditions of increasing returns to scale and specialization.

Some theoretical studies suggest that trade openness sometimes hampers economic growth although it may potentially stimulate growth (Zahonogo, 2016: 42). According to Lucas (1988), Young (1991), and Redding (1999), opening up to trade may reduce long-term growth if a country specializes in comparatively disadvantaged sectors where potential productivity growth, technological innovations or learning by doing have largely lost effectiveness. In such economies, the selection of appropriate protectionist policies in foreign trade can accelerate technological progress.

\section{LITERATURE REVIEW}

The academic studies conducted throughout the world about the subject are summarized in Table 1. When the results of the study given in the table are analysed, it is understood that there is no consensus on the effect of trade liberalization on economic growth. Hence, the hypothesis on the theoretical level in terms of the relationship between trade liberalization and economic growth differs depending on the period examined, country and foreign trade policies. In general, however, the existence of a mutual and the same directional causal relation between free trade and economic growth has been determined. In most cases, conclusions have been reached in accordance with endogenous growth theories that say that trade liberalisation has a positive effect on economic growth.

Table 1: Empirical Literature Review

\begin{tabular}{|l|l|l|}
\hline Researcher & $\begin{array}{l}\text { Data Span and } \\
\text { Methodology }\end{array}$ & Findings \\
\hline Tullock (1967) & Theoretical Study & $\begin{array}{l}\text { Suggested that the elimination of the social welfare costs of rent- } \\
\text { seeking activities, protectionism, monopolies and customs tariffs } \\
\text { would significantly increase domestic income. }\end{array}$ \\
\hline Ram (1985) & $\begin{array}{l}\text { 1960-1970 and 1970- } \\
1977,73 \text { Countries, Cross- } \\
\text { Section Analysis }\end{array}$ & $\begin{array}{l}\text { In his analysis with country dummy variables based on the real } \\
\text { growth rate of labor and exports and the share of investments in } \\
\text { GDP, found a positive correlation between foreign trade and } \\
\text { economic growth, but state that this is due to foreign demand. }\end{array}$ \\
\hline $\begin{array}{l}\text { Grossman and } \\
\text { Helpman (1991) }\end{array}$ & Theoretical Study & $\begin{array}{l}\text { Stated that economies of scale, technological innovations and rapid, } \\
\text { high quality and low-cost production will bring competition, thus } \\
\text { increase economic growth by providing dynamic gains from trade. }\end{array}$ \\
\hline $\begin{array}{l}\text { Levine and Renelt } \\
(1992)\end{array}$ & $\begin{array}{l}1960-1989,119 \text { Countries, } \\
\text { Cross-Section and } \\
\text { Sensitivity Analysis }\end{array}$ & $\begin{array}{l}\text { In their study for developed and developing countries, found that } \\
\text { there is a strong relationship between trade and investments, and } \\
\text { between investments and economic growth. Moreover, they } \\
\text { suggest that trade liberalization positively affects economic growth } \\
\text { through investments. }\end{array}$ \\
\hline $\begin{array}{l}\text { Sprout and Weaver } \\
(1993)\end{array}$ & $\begin{array}{l}\text { 1970-1984, 72 Less } \\
\text { Developed Countries, }\end{array}$ & $\begin{array}{l}\text { In their analysis, they divided the countries into three groups } \\
\text { according to their dependence on exports and used the variables of }\end{array}$ \\
\hline
\end{tabular}




\begin{tabular}{|c|c|c|}
\hline & $\begin{array}{l}\text { Two-stage Least Squares } \\
\text { Method }\end{array}$ & $\begin{array}{l}\text { the average labor force growth rate and the share of investment } \\
\text { and exports in real GDP. Authors found statistically significant and } \\
\text { positive relationships in oil exporting countries, but no correlation } \\
\text { between economic growth and trade liberalization in countries with } \\
\text { primary commodity exporters. }\end{array}$ \\
\hline $\begin{array}{l}\text { Greenaway et al. } \\
\text { (1997) }\end{array}$ & $\begin{array}{l}\text { 1950-1985, } 13 \text { Developing } \\
\text { Countries, Time Series } \\
\text { Analysis }\end{array}$ & $\begin{array}{l}\text { Found no linear relation between trade liberalization and economic } \\
\text { growth and observe that in the early periods of liberalization, the } \\
\text { economy shrinks and that there is an increase in growth in the later } \\
\text { periods. }\end{array}$ \\
\hline Edwards (1997) & $\begin{array}{l}\text { 1980-1990, } 93 \text { Countries, } \\
\text { Panel Data Analysis }\end{array}$ & $\begin{array}{l}\text { Concluded that foreign trade increases total factor productivity and } \\
\text { thus economic growth. }\end{array}$ \\
\hline $\begin{array}{l}\text { Frankel and Romer } \\
\text { (1999) }\end{array}$ & $\begin{array}{l}\text { Year 1985, } 150 \text { Countries, } \\
\text { Least Squares Method }\end{array}$ & $\begin{array}{l}\text { In their study using the geographical components of trade, have } \\
\text { addressed the ratio of trade to GDP as a function of geographic } \\
\text { factors; and concluded that a non-coastal country has a low level of } \\
\text { foreign trade and trade partners' distance from each other } \\
\text { adversely affects trade. In the study, it is found that a } 1 \% \text { increase in } \\
\text { the share of import and export increases the GDP per capita by } 2 \% \\
\text { or more. }\end{array}$ \\
\hline $\begin{array}{l}\text { Abu-Qarn and } \\
\text { Abubader (2001) }\end{array}$ & $\begin{array}{l}\text { The Middle Eastern and } \\
\text { North African Countries, } \\
\text { 1968-1996 (Algeria and } \\
\text { Sudan) } \\
\text { 1966-1996 (Egypt, } \\
\text { Morocco, Tunisia, Turkey) } \\
\text { 1974-1995 (Iran) } \\
\text { 1976-1996 (Israel), Time } \\
\text { Series Analysis }\end{array}$ & $\begin{array}{l}\text { Found that while exports and manufacturing industry exports } \\
\text { increase economic growth in Algeria and Sudan, there is no such } \\
\text { relationship for other countries. }\end{array}$ \\
\hline $\begin{array}{l}\text { Greenaway et al. } \\
\text { (2002) }\end{array}$ & $\begin{array}{l}\text { Data for the Last } 20 \text { Years, } \\
73 \text { Developing Countries, } \\
\text { Panel Data Analysis }\end{array}$ & $\begin{array}{l}\text { Observed that trade liberalization adversely affects the GDP per } \\
\text { capita, but this negativity disappears and economic growth } \\
\text { improves over time. The results of the study show that there is a } \\
\text { relationship between the variables in the shape of a "J" curve. }\end{array}$ \\
\hline Vamvakidis (2002) & $\begin{array}{l}\text { 1920-1990, } 62 \text { Countries, } \\
\text { Regression Analysis }\end{array}$ & $\begin{array}{l}\text { Suggested that the relationship between trade liberalization and } \\
\text { economic growth is negative for the period of } 1920-1940, \text { but } \\
\text { positive for 1970-1990. On the other hand, the author couldn't find } \\
\text { any correlation between the variables for the period of 1950-1970. }\end{array}$ \\
\hline Yanikkaya (2003) & $\begin{array}{l}\text { 1970-1997, } 100 \text { Countries, } \\
\text { Panel Data Analysis }\end{array}$ & $\begin{array}{l}\text { Although he found positive relations between Export/GDP, } \\
\text { Import/GDP and Export + Import / GDP and economic growth; } \\
\text { found that there is a relationship between the tariffs, export taxes, } \\
\text { the taxes on foreign trade and growth, which are contrary to the } \\
\text { literature. That is to say, as trade barriers increase, economic } \\
\text { growth will increase. }\end{array}$ \\
\hline $\begin{array}{l}\text { Dollar and Kraay } \\
\text { (2004) }\end{array}$ & $\begin{array}{l}\text { 1975-1997, } 101 \\
\text { Developed and } \\
\text { Developing Countries, } \\
\text { Time Series Analysis }\end{array}$ & $\begin{array}{l}\text { Found a positive relationship between the share of foreign trade in } \\
\text { GDP and growth. The results of the study show that developing } \\
\text { countries which significantly reduce tariffs with globalization } \\
\text { process grow faster than developing countries which are not open } \\
\text { to foreign trade and even developed countries. }\end{array}$ \\
\hline $\begin{array}{l}\text { Santos-Paulino and } \\
\text { Thirlwall (2004) }\end{array}$ & $\begin{array}{l}\text { 1972-1997, } 22 \text { Developing } \\
\text { Countries, Panel Data } \\
\text { Analysis }\end{array}$ & $\begin{array}{l}\text { Found that the increase in export due to trade liberalization has an } \\
\text { impact on income distribution, wage inequality, employment and } \\
\text { economic growth. Authors conclude that the increase in import has } \\
\text { weaker effects on these variables and liberalization worsens the } \\
\text { countries' balance of payments by increasing imports more. }\end{array}$ \\
\hline Samman (2005) & $\begin{array}{l}\text { 1985-2003, } 100 \text { Countries, } \\
\text { Time Series Analysis }\end{array}$ & $\begin{array}{l}\text { Handled the work of Dollar and Kraay (2004) with a different } \\
\text { methodology. Author put forward that the share of foreign trade in } \\
\text { GDP, which he takes as a criterion for trade liberalization, yield } \\
\text { misleading results. In the study, it is determined that trade } \\
\text { liberalization considerably affects economic growth in the long- } \\
\text { term. But the size and direction of the relationship between } \\
\text { variables is not clear. }\end{array}$ \\
\hline
\end{tabular}




\begin{tabular}{|c|c|c|}
\hline $\begin{array}{l}\text { Parida and Sahoo } \\
\text { (2007) }\end{array}$ & $\begin{array}{l}\text { 1980-2002, } 4 \text { South Asian } \\
\text { Countries (India, Pakistan, } \\
\text { Bangladesh, Sri Lanka), } \\
\text { Panel Data Analysis }\end{array}$ & $\begin{array}{l}\text { Propound evidence supporting the hypothesis that exports and } \\
\text { manufacturing exports increase economic growth. }\end{array}$ \\
\hline $\begin{array}{l}\text { Kılavuz and Topçu } \\
\text { (2012) }\end{array}$ & $\begin{array}{l}\text { 1998-2006, } 22 \text { Developing } \\
\text { Countries, Panel Data } \\
\text { Analysis }\end{array}$ & $\begin{array}{l}\text { Found that high-technology manufacturing industry export, } \\
\text { investment and low-technology manufacturing industry import } \\
\text { have a significant and positive effect on growth. }\end{array}$ \\
\hline Gül et al. (2013) & $\begin{array}{l}\text { 1994-2010, } 6 \text { Countries } \\
\text { (Kazakhstan, Krgyzstan, } \\
\text { Uzbekistan, Tajikistan, } \\
\text { Turkmenistan and } \\
\text { Turkey), Panel Granger } \\
\text { Causality Test }\end{array}$ & $\begin{array}{l}\text { Found a positive relationship between economic growth and } \\
\text { foreign trade in the long-term. }\end{array}$ \\
\hline $\begin{array}{l}\text { Bourdon et al. } \\
\text { (2013) }\end{array}$ & $\begin{array}{l}\text { 1995-2009, } 157 \text { Countries, } \\
\text { GMM Method }\end{array}$ & $\begin{array}{l}\text { Showed different results in different country groups and determine } \\
\text { that trade liberalization affects economic growth negatively in } \\
\text { countries where exports vary. }\end{array}$ \\
\hline Dao (2014) & $\begin{array}{l}\text { 1980-2009, } 71 \text { Countries, } \\
\text { Panel Data Analysis }\end{array}$ & $\begin{array}{l}\text { Found a statistically significant and positive relationship between } \\
\text { trade liberalization and economic growth. }\end{array}$ \\
\hline $\begin{array}{l}\text { Sağlam and Egeli } \\
\text { (2015) }\end{array}$ & $\begin{array}{l}\text { 1999-2013, Turkey, } \\
\text { Granger Causality Test }\end{array}$ & $\begin{array}{l}\text { In the short-term, they found a bidirectional causality between two } \\
\text { variables; but in the long-term, only unidirectional causality from } \\
\text { export to growth. }\end{array}$ \\
\hline Zahonogo (2016) & $\begin{array}{l}\text { 1980-2012, } 42 \text { Sub- } \\
\text { Saharan Africa Countries, } \\
\text { Pooled Mean Group } \\
\text { Estimation Technique }\end{array}$ & $\begin{array}{l}\text { Introduced the existence of a trade threshold below which greater } \\
\text { trade liberalization positively affects economic growth and above } \\
\text { which the impact of trade on growth decreases. The empirical } \\
\text { results show an inverted-U curve response, indicating the non- } \\
\text { fragility of the association between free trade and growth for SSA } \\
\text { countries. The results of the study reveal that free trade can } \\
\text { influence growth in the long-term, but the linkage between the } \\
\text { variables is not linear. }\end{array}$ \\
\hline Idris et al. (2016) & $\begin{array}{l}\text { 1977-2011, } 87 \text { Developed } \\
\text { Countries, GMM }\end{array}$ & $\begin{array}{l}\text { Indicated that trade liberalization has a positive impact on } \\
\text { economic growth. This result is consistent with the endogenous } \\
\text { theory. }\end{array}$ \\
\hline Acet et al. (2016) & $\begin{array}{l}\text { 1998-2013, Turkey, } \\
\text { Granger Causality Test }\end{array}$ & $\begin{array}{l}\text { Suggested that there is a unidirectional causality from both export } \\
\text { and import to economic growth. However, they emphasize that the } \\
\text { effect of export on growth is based on imported inputs and } \\
\text { highlight the impact of imports on growth. }\end{array}$ \\
\hline Şerefli (2016) & $\begin{array}{l}\text { 1975-2014, Turkey, } \\
\text { Granger Causality Test }\end{array}$ & $\begin{array}{l}\text { Could not find a causal relationship between the variables of export, } \\
\text { import and economic growth. }\end{array}$ \\
\hline $\begin{array}{l}\text { Silajdzic and Mehic } \\
\text { (2017) }\end{array}$ & $\begin{array}{l}\text { 1992-2014, EU Transition } \\
\text { Economies, CCE }\end{array}$ & $\begin{array}{l}\text { Argued that trade liberalization positively affects economic growth } \\
\text { in countries which use technology intensive methods of production. }\end{array}$ \\
\hline $\begin{array}{l}\text { Tunçsiper and } \\
\text { Rençber (2017) }\end{array}$ & $\begin{array}{l}\text { 2002-2016, Turkey, } \\
\text { Granger Causality Test }\end{array}$ & $\begin{array}{l}\text { Asserted that there is a unidirectional causality from import to } \\
\text { economic growth and export. The results obtained from this study } \\
\text { prove the validity of "import-push growth" and "import-based } \\
\text { export" hypotheses for Turkish economy. }\end{array}$ \\
\hline Özcan et al. (2018) & $\begin{array}{l}\text { 1992-2015, } 18 \text { Emerging } \\
\text { Market Economies, Panel } \\
\text { Data Analysis }\end{array}$ & $\begin{array}{l}\text { Suggested that there is a causal relationship between variables, } \\
\text { from GDP per capita to trade liberalization. }\end{array}$ \\
\hline $\begin{array}{l}\text { Yurdakul and Aydın } \\
\text { (2018) }\end{array}$ & $\begin{array}{l}\text { 2003-2016 and 2008- } \\
\text { 2016, Turkey, Engle- } \\
\text { Granger, Johansen and } \\
\text { Dynamic Least Squares }\end{array}$ & $\begin{array}{l}\text { The results of the analysis using the real values of the variables } \\
\text { show the validity of the import-oriented growth hypothesis for } \\
\text { Turkey during the period 2003-2016; but when the nominal values } \\
\text { of the variables are used, it is seen that there is a long-term } \\
\text { equilibrium relationship between variables and the export-led } \\
\text { growth hypothesis holds true for the country. On the other hand, in } \\
\text { the analysis carried out for the period of 2008-2016, it is concluded } \\
\text { that the export-oriented growth hypothesis is valid in Turkish } \\
\text { economy. }\end{array}$ \\
\hline
\end{tabular}

\section{ECONOMETRIC ANALYSIS}




\subsection{Data Set, Variables, Methodology}

The dataset includes 312 observations from 1995 to 2016 for the variables of "gross domestic product (GDP), export (EXP), import (IMP), gross fixed capital formation (GFCF), foreign direct investment (FDI) and human capital (HC)" belong to 13 transition economies 1 of European Union. The data set was obtained from World Bank database.

In this study, primarily, the functional, the statistical and the VAR model will be defined. Before examining the long-term relationships and the short-term causality between the series, the correlation between the units, the stationaries of the series and the homogeneity of the parameters will be tested so as to define the appropriate panel causality and cointegration testing method. By considering the test results it will be defined the short-term causality test method and panel cointegration test method that reveals the long-term relationships.

\subsection{Model}

The functional expression of the model can be described as in Eq.1. In the model GDP represents the economic growth and is the predicated variable of the model, while exports (EXP), imports (IMP), Gross fixed capital formation (GFCF), foreign direct investment (FDI) and human capital $(\mathrm{HC})$ are the predictor variables of the model.

$$
G D P=f(E X P, I M P, G F C F, F D I, H C)
$$

$$
\begin{array}{ll}
\text { GDP } & : \text { "Gross Domestic Product (constant } 2010 \text { US\$)" } \\
\text { EXP } & : \text { :Exports of goods and services (constant } 2010 \text { US\$)" } \\
\text { IMP } & : \text { "Imports of goods and services (constant } 2010 \text { US\$)" } \\
\text { GCFC } & : \text { "Gross fixed capital formation (constant } 2010 \text { US\$)" } \\
\text { FDI } & : \text { :Foreign direct investment, net inflows (BoP, current US\$)" } \\
\text { HC } & : \text { :Secondary education, pupils" }
\end{array}
$$

It is needed to convert the functional model to statistical model to carry on analysis. Eq.2 shows the statistical model below.

$$
G D P_{i t}=a+\beta_{1} E X P_{i t}+\beta_{2} I M P_{i t}+\beta_{3} G F C F_{i t}+\beta_{4} F D I_{i t}+\beta_{5} H C_{i t}+u_{i t}
$$

In equation (2), a symbolises the "constant term", while $\beta$ typifies the coefficients that specify the relationship between the predicated variable and the predictor variables; $i(i=1 \ldots . N)$ denotes the countries, and $u_{i t}$ refers to the error term.

The VAR model can be described with the dynamic equation, which is defined by taking the delayed values of the series, as in Eq.3

$$
\begin{aligned}
& d G D P_{t}=a_{1}+\sum_{l=1}^{n} \beta_{1 l} d G D P_{i t-l}+\sum_{l=1}^{n} \beta_{2 l} d E X P_{i t-l}+\sum_{l=1}^{n} \beta_{3 l} d I M P_{i t-l}+\sum_{l=1}^{n} \beta_{4 l} d G C F C_{i t-l}+ \\
& \sum_{l=1}^{n} \beta_{5 l} d F D I_{i t-l}+\sum_{l=1}^{n} \beta_{6 l} d H C_{i t-l}+u_{1 t} \\
& d E X P_{t}=a_{2}+\sum_{l=1}^{n} \beta_{7 l} d E X P_{i t-l}+\sum_{l=1}^{n} \beta_{8 l} d G D P_{i t-l}+\sum_{l=1}^{n} \beta_{9 l} d I M P_{i t-l}+\sum_{l=1}^{n} \beta_{10 l} d G C F C_{i t-l}+ \\
& \sum_{l=1}^{n} \beta_{11 l} d F D I_{i t-l}+\sum_{l=1}^{n} \beta_{12 l} d H C_{i t-l}+u_{2 t} \\
& d I M P_{t}=a_{3}+\sum_{l=1}^{n} \beta_{10 l} d I M P_{i t-l}+\sum_{l=1}^{n} \beta_{11 l} d E X P_{i t-l}+\sum_{l=1}^{n} \beta_{12 l} d G D P_{i t-l}+\sum_{l=1}^{n} \beta_{13 l} d G C F C_{i t-l}+ \\
& \sum_{l=1}^{n} \beta_{14 l} d F D I_{i t-l}+\sum_{l=1}^{n} \beta_{15 l} d H C_{i t-l}+u_{3 t} \\
& d G C F C_{t}=a_{4}+\sum_{l=1}^{n} \beta_{16 l} d G C F C_{i t-l}+\sum_{l=1}^{n} \beta_{17 l} d E X P_{i t-l}+\sum_{l=1}^{n} \beta_{18 l} d I M P_{i t-l}+\sum_{l=1}^{n} \beta_{19 l} d G D P_{i t-l}+ \\
& \sum_{l=1}^{n} \beta_{20 l} d F D I_{i t-l}+\sum_{l=1}^{n} \beta_{21 l} d H C_{i t-l}+u_{4 t} \\
& d F D I_{t}=a_{5}+\sum_{l=1}^{n} \beta_{22 l} d F D I_{i t-l}+\sum_{l=1}^{j n} \beta_{23 l} d E X P_{i t-l}+\sum_{l=1}^{n} \beta_{24 l} d I M P_{i t-l}+\sum_{l=1}^{n} \beta_{25 l} d G C F C_{i t-l}+ \\
& \sum_{l=1}^{n} \beta_{26 l} d G D P_{i t-l}+\sum_{l=1}^{n} \beta_{27 l} d H C_{i t-l}+u_{5 t}
\end{aligned}
$$

\footnotetext{
${ }^{1}$ These transition countries are "Albania, Bulgaria, Croatia, Czech, Estonia, Hungary, Latvia, Lithuania, Macedonia, Poland, Romania, Slovak Rep. and Slovenia."
} 


$$
\begin{aligned}
& d H C_{t}=a_{6}+\sum_{l=1}^{n} \beta_{28 l} d H C_{i t-l}+\sum_{l=1}^{n} \beta_{29 l} d E X P_{i t-l}+\sum_{l=1}^{n} \beta_{30 l} d I M P_{i t-l}+\sum_{l=1}^{n} \beta_{31 l} d G C F C_{i t-l}+ \\
& \sum_{l=1}^{n} \beta_{32 l} d F D I_{i t-l}+\sum_{l=1}^{n} \beta_{33 l} d G D P_{i t-l}+u_{6 t}
\end{aligned}
$$

In Eq.3 $d$ displays "the first difference for the relevant series", $u_{1 t}, \ldots, u_{6 t}$ denote the "error terms". It is assumed that the lagged values of the variables are the same and are symbolised as $n$ in each of equations. VAR Model is a system of equations in which each variable is linear function that covers lagged values of both predicated variable itself and other variables in the system. Therefore, the current values of the predicated variables are at the left side of the equation. The lagged values of all series are at the right side of the equation.

\subsection{Application and Findings}

In order to carry on the causality analysis, the series should be stationary at the same level. Therefore, primarily, the stationarity of the series will be determined by proper unit root test. So as to select the appropriate unit root test, the existence of correlation between the units should be tested. If there is a correlation between the units, "the first-generation panel unit root tests", if not, "the second-generation panel unit root tests" will be employed.

\subsubsection{Cross Dependence Analysis}

The correlations between the units was examined with "Pesaran 2004 Cross-section Dependence Test" and the outcomes are summarized in Table 3.

\begin{tabular}{|c|c|c|c|c|}
\hline Variables & CD-test & $p$-value & Corr & Abs(corr) \\
\hline LnGDP & 40.34 & $0.000 *$ & 0.960 & 0.960 \\
\hline LnEXP & 39.94 & $0.000 *$ & 0.951 & 0.951 \\
\hline LnIMP & 40.75 & $0.000 *$ & 0.970 & 0.970 \\
\hline LnGFCF & 34.52 & $0.000^{*}$ & 0.822 & 0.822 \\
\hline LnFDI & 26.55 & $0.000^{*}$ & 0.633 & 0.633 \\
\hline LnHCS & 34.91 & $0.000 *$ & 0.830 & 0.830 \\
\hline MODEL - mgres & 6.49 & $0.000 *$ & 0.155 & 0.225 \\
\hline
\end{tabular}

Table 2: CD-Test

Note: Under the null hypothesis of cross-section independence $C D \sim N(0,1)$

In Table 2, shows the values of CD-test statistics, probabilities, correlation coefficients and the absolute correlation coefficients. According to the test results, the p-values of the variables are less than 0.05 . Therefore, "the null hypothesis that presents no correlation between units" was rejected and it is concluded the existence of correlation. Therefore, "the second generation unit root tests" should be preferred to test the stationary of the series.

\subsubsection{Stationary Analysis}

Pesaran (2007) added the "cross-sectional averages of the lagged values of the series" at level, and at the first order differences of the series as factors to the DF or ADF regression so as to eliminate the correlation between the units. Thus, in this method, the ADF regression was extended by the lagged values of cross-sectional averages and the first differences of this regression obscures the correlation between the units. The results of CIPS tests developed by Im, Pesaran and Shin are given in Table 4.

Table 3: Pesaran CIPS Unit Root Test

\begin{tabular}{l|cccccc}
\hline \hline lag & t-bar & cv10 & cv5 & cv1 & Z[t-bar] & P-value \\
\hline \hline LnGDP & -2.536 & -2.140 & -2.250 & -2.450 & -2.847 & $0.002^{*}$ \\
\hline LnEXP & -2.383 & -2.140 & -2.250 & -2.450 & -2.277 & $0.011^{* *}$ \\
\hline LnIMP & -2.798 & -2.140 & -2.250 & -2.450 & -3.819 & $0.000^{*}$ \\
\hline LnGFCF & -2.708 & -2.140 & -2.250 & -2.450 & 3.488 & $0.000^{*}$ \\
\hline LnFDI & -2.492 & -2.140 & -2.250 & -2.450 & -2.684 & $0.004^{*}$ \\
\hline LnHCS & -2.775 & -2.140 & -2.250 & -2.450 & -3.736 & $0.000^{*}$ \\
\hline \hline
\end{tabular}

Based on the results of Table 3, because of the "absolute values of t-bar (CIPS) statistics" are greater than the absolute values of the confidence level at $\% 1, \% 5$ and $\% 10$, it is concluded that the series are "stationary at level." Similarly, due to the pvalues of Z [t-bar] statistics of all series are less than 0.05 and therefore the series are stationary at the level. 


\subsubsection{Homogeneity Analysis}

Before implementing causality analysis, it is needed to be determined the homogeneity of the parameters, so as to define whether the heterogeneous panel data analysis or homogenous panel data analysis will be employed. For this purpose, Swamy S Homogeneity Test was employed and the outcomes are presented in Table 4.

Table 4: Homogeneity Test

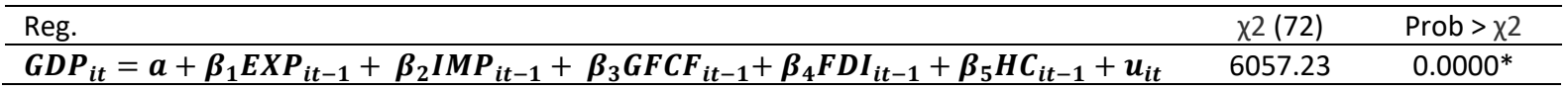

"HO: parameters are homogeneous" the null hypothesis is tested against "HA: parameters are heterogeneous" the alternative hypothesis. Because the probability value of $\chi 2$ presented in Table 5 is less than 0.05 , "HO hypothesis is rejected and It is concluded that the parameters are heterogeneous". Therefore, heterogeneity will be taken into consideration when determining the appropriate method for panel causality and cointegration tests.

\subsubsection{Short-Term Causality Analysis}

In the short-term causality analysis between the series, Dumitrescu \& Hurlin (2012) Granger Panel Causality Test, which takes into account the heterogeneity, is employed and the outcomes are shown in Table 6.

Table 5: VAR Panel Causality Test Results

\begin{tabular}{|c|c|c|c|c|c|}
\hline $\mathrm{H}_{0}$ : & & & W-bar Stat. & Z-bar Stat. (p-value) & Z-bar tilde ( $p$-value) \\
\hline EXP & $\nRightarrow$ & GDP & 3.5031 & $6.3817(0.0000)^{*}$ & $5.0367(0.0000)^{*}$ \\
\hline GDP & $\nRightarrow$ & EXP & 1.9851 & $2.5115(0.0120)^{* *}$ & $1.8403(0.0657)^{* * *}$ \\
\hline IMP & $\nRightarrow$ & GDP & 2.9141 & $4.8800(0.0000)^{*}$ & $3.7965(0.0001)^{*}$ \\
\hline GDP & $\nRightarrow$ & IMP & 0.6117 & $-0.9901(0.3221)$ & $-1.0516(0.2930)$ \\
\hline GFCF & $\nRightarrow$ & GDP & 14.0818 & $8.4118(0.0000)^{*}$ & $0.8497(0.3955)$ \\
\hline GDP & $\nRightarrow$ & GFCF & 15.6958 & $10.0917(0.0000)^{*}$ & $1.1857(0.2358)$ \\
\hline FDI & $\nRightarrow$ & GDP & 4.0020 & $7.6537(0.0000)^{*}$ & $6.0872(0.0000)^{*}$ \\
\hline GDP & $\nRightarrow$ & FDI & 2.4531 & $3.7047(0.0002) *$ & $2.8257(0.0047) *$ \\
\hline $\mathrm{HC}$ & $\nRightarrow$ & GDP & 18.9783 & $13.5083(0.0000)^{*}$ & $1.8690(0.0616)^{* *}$ \\
\hline GDP & $\nRightarrow$ & $\mathrm{HC}$ & 28.5712 & $23.4929(0.0000) *$ & $3.8659(0.0001)^{*}$ \\
\hline
\end{tabular}

Note: “*, ** and *** indicates the granger causality at \%1, 5\% and $10 \%$ significance level respectively”.

$(\nRightarrow)$ refers "does not Granger-cause"

Dumitrescu \& Hurlin (2012) Granger Panel Causality Test Results, which are seen in Table 5, indicated that:
a) EXP is the granger cause of GDP
b) GDP is the granger cause of EXP.
c) IMP is the granger-cause of GDP
d) GDP is not the granger-cause of IMP
e) GFCF is the granger-cause of GDP
f) GDP is the granger-cause of GFCF
g) $\mathrm{FDI}$ is the granger cause of GDP
h) GDP is the granger cause of FDI
i) $\mathrm{HC}$ is the granger-cause of GDP
j) GDP is the granger-cause of $\mathrm{HC}$

As a result, there is bi-directional causality between EXP and GDP; GFCF and GDP; FDI and GDP, HC and GDP and unidirectional causality from IMP to GDP. The outcomes of the short-term analysis are presented in Table 6. 
Table 6: Short-Term Relationships

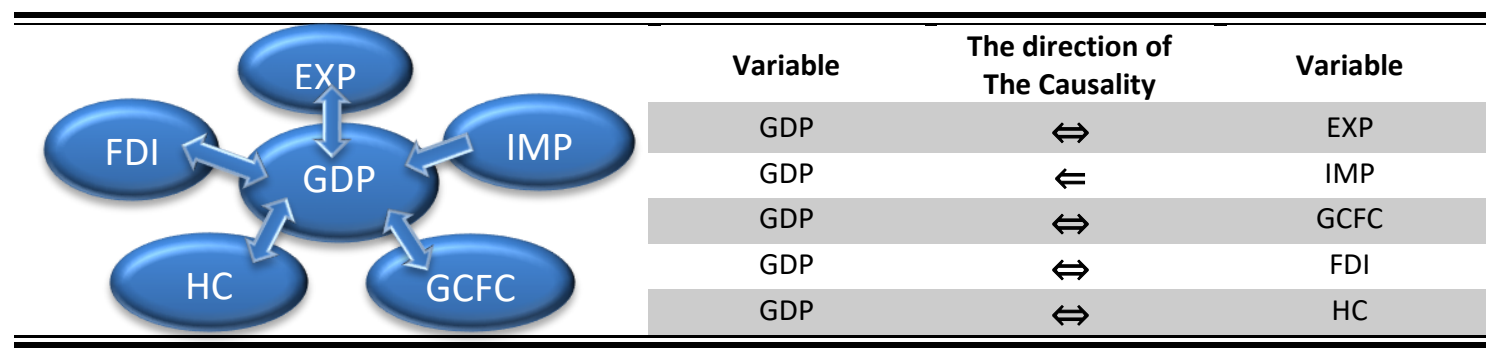

\subsubsection{Long-Term Analysis}

Despite of a permanent shocks that affect the system, it is possible a long-term equilibrium relationship between the variables. The existence of these relationships is analysed by using cointegration tests. In the panel cointegration tests, the appropriate method is determined according to the existence of correlation between the units and homogeneity of the parameters. As Pesaran CD-Test indicated a correlation between the units and Swamy S Test indicated that parameters are heterogonous, to test the long-term relationships, PDOLS Estimator the second-generation method, which considers the heterogeneity and correlation. However, before implementing PDOLS Estimator, Westerlund Panel Cointegration test will be conducted to show whether a long-term relationship exist, or not.

Table 7: Westerlund ECM Panel Co-integration Test

\begin{tabular}{lcccc}
\hline \hline Statistics & Value & Z-value & P-value & Robust p-value \\
\hline \hline $\mathrm{G}_{\mathrm{t}}$ & -2.818 & -2.941 & 0.002 & $0.020^{*}$ \\
\hline $\mathrm{G}_{\mathrm{a}}$ & -6.935 & 1.492 & 0.932 & $0.080^{* *}$ \\
\hline $\mathrm{P}_{\mathrm{t}}$ & -9.148 & -2.619 & 0.004 & $0.030^{*}$ \\
\hline $\mathrm{P}_{\mathrm{a}}$ & -7.275 & -0.573 & 0.283 & $0.040^{*}$ \\
\hline \hline
\end{tabular}

Notes: "* and * indicate cointegration at the significance level of $5 \%$ and $10 \%$ respectively".

Table 7 includes Gt, Ga, Pt and Pa the test statistics, Z statistics, probability values (P-value) and robust $p$-values. The laglength is determined as 0.46 according to average Akaike information criterion. The null hypothesis, which represents "HO: no cointegration" is tested. Robust $p$-values are the results should be take into consideration for heterogeneous panel cointegration. When these results are examined, robust p-values of Gt, Pt and Pa are less than 0.05 and $\mathrm{Ga}$ is less then 0.10 . Therefore, the "HO hypothesis is rejected" and It was concluded that there is a co-integration between the series.

Since a long-term relationship between the series was confirmed, to get further detail in long-term relationships, PDOLS Estimator Test was implemented and the outcomes are displayed in Table 9.

Table 8: PDOLS Estimator Outcomes

\begin{tabular}{|c|c|c|}
\hline \hline Variables & Beta & t-stat \\
\hline \hline EXP & .3922 & $2.06 \mathrm{e}+13$ \\
\hline IMP & .1073 & $5.05 \mathrm{e}+12$ \\
\hline GFCF & .3735 & $3.51 \mathrm{e}+13$ \\
\hline FDI & $-1.35 \mathrm{e}-11$ & $-9.86 \mathrm{e}+12$ \\
\hline $\mathrm{HC}$ & .5436 & $2.26 \mathrm{e}+12$ \\
\hline \hline
\end{tabular}

Note: "t-statistic table value $(\alpha=0.05)$ is $1,96 . "$

According to the results seen in Table 8, the EXP, IMP, GFCF, FDI and HC variables are significant because the absolute values of calculated t-statistics at $95 \%$ the confidence level are greater than 1.96 which is the t-statistic table value. Accordingly, the long-term relationship between the variable are presented in Table 9. 


\section{Table 9: Summary of Long-Term Outcomes}

(1) a $1 \%$ raise in EXP boosts the GDP by 0.39

(2) a $1 \%$ raise in IMP boosts GDP by $0.11 \%$

(3) a $1 \%$ raise in GFCF boosts GDP by $0.37 \%$

(4) a $1 \%$ raise in FDI reduces GDP by $1.35 \%$

(5) a $1 \%$ raise in $\mathrm{HC}$ boosts GDP by $0.54 \%$

\begin{tabular}{ccc} 
a $1 \%$ i in EXP & $\Rightarrow$ & a $0.39 \%$ i in GDP \\
a $1 \%$ in inP & $\Rightarrow$ & a $0.11 \%$ i in GDP \\
a $1 \%$ i in GFCF & $\Rightarrow$ & a $0.37 \%$ in GDP \\
a $1 \%$ i in FDI & $\Rightarrow$ & a $1.35 \%$ in GDP \\
a $1 \%$ i in HC & $\Rightarrow$ & a $0.54 \%$ i in GDP \\
\hline
\end{tabular}

\section{CONCLUSION}

When the literature is examined, it is seen that that there is no congruity on the effect of trade liberalization on economic growth. Hence, the hypotheses on the theoretical level in the sense of the connection between trade liberalization and economic growth differs depending on the period examined, country, foreign trade policies and the empirical methods employed. In general, however, the existence of a mutual and the same directional causality between trade liberalization and economic growth has been determined. In most cases, conclusions have been reached in accordance with endogenous growth theories that say that trade liberalisation has a positive effect on economic growth.

In this study, the long-term and the short-term relationships between economic growth and trade liberalization for 13 transition countries in Europe was examined. The dataset includes 312 observations from 1995 to 2016 for the variables of gross domestic product (GDP), export (EXP), import (IMP), gross fixed capital formation (GFCF), foreign direct investment (FDI) and human capital (HC).

Primarily, the functional, the statistical and the VAR models were established, the significances of the variables, model, and the coefficients were revealed by implementing PLS Method. Before examining the long-term relationships and the shortterm causality between the series, (i) the correlation between the units tested with the help of Pesaran CD-Test; (ii) the stationaries of the series investigated via Pesaran (2007) Unit Root Test; (iii) the homogeneity of the parameters were tested by implementing Swamy S Test. it is concluded that units are correlated and the model is heterogeneous. Therefore, to test the short-term causality Dumitrescu \& Hurlin (2012) Granger Panel Causality Test, which takes into account the heterogeneity was preferred, and to test long-term relationships PDOLS Heterogeneous Estimator was employed.

Dumitrescu \& Hurlin (2012) Granger Panel Causality Test Results revealed a bidirectional causality between (a) EXP and GDP, (b) GFCF and GDP, (c) FDI and GDP, (d) HC and GDP, and a unidirectional causality from IMP to GDP.

Westerlund ECM Panel Co-integration test results confirmed long-term relationships. Then, PDOLS Estimator revealed that (1) a $1 \%$ raise in EXP boosts GDP by 0.39 , (2) a $1 \%$ raise in IMP boosts GDP by $0.11 \%$ (3) a $1 \%$ raise in GFCF boosts GDP by $0.37 \%$ (4) a $1 \%$ raise in FDI reduces GDP by $1.35 \%$, (5) a $1 \%$ raise in $\mathrm{HC}$ boosts GDP by $0.54 \%$ in the long-term.

The results of both the short-term and the long-term shows that the trade liberalization has a positive influence on economic growth mutually between EXP, IMP and GDP as it is argued by the feed-back hypothesis. 


\section{REFERENCES}

Abu-Qarn, A. and Abubader, S. (2001). Export-led growth: empirical evidence from the MENA region. Ben Gurion University Monaster Center for Economic Research, 1-34.

Acet, H., Erdoğan, S. and Köksal, M. (2016). İthalat, ihracat ve büyüme arasındaki nedensellik ilişkisi: Türkiye uygulaması. Sosyal ve Ekonomik Araştırmalar Dergisi, 16 (31), 145-161.

Balassa, B. (1985). Exports, policy choices, and economic growth in developing countries after the 1973 oil shock. Journal of Development Economics, $18(1), 23-35$.

Bourdon, M., Mouél, C. and Vijil, M. (2013). The relationship between trade openness and economic growth: some new insights on the openness measurement issue. Hall-Archives, Ouvertes. Fr, Hal Id: 00729399, 1-18.

Çeliköz, Y., Barutçu, E. ve Afsal, M. (2017). Ticari dışa açıklık ve ekonomik büyüme arasındaki ilişki; Türkiye örneği. Route Educational and Social Science Journal, 4 (7), 104-118.

Dao, A. (2014). Trade openness and economic growth. Mark A. Israel '91 Endowed Summer Research Fund in Economics. 2. https://core.ac.uk/download/pdf/59252729.pdf (Erişim tarihi: 09.02.2019)

Dollar, D. and Kraay, A. (2004). Trade, growth, and poverty. The Economic Journal, 114 (493), 22-49.

Edwards, S. (1997). Openness, productivity and growth. What do we really know?. NBER Working Papers, No: 5978.

Emsen, Ö. ve Değer, M. (2007). Ticari ve siyasal liberalizasyon ve ekonomik büyüme ilişkileri: geçiş ekonomileri deneyimi. Atatürk Üniversitesi iktisadi ve Idari Bilimler Dergisi, 21 (2), 161-195.

Federici, D. and Marconi, D. (2002). On exports and economic growth: the case of Italy. Journal of International Trade and Economic Development, 11 (3), 323-340.

Frankel, J. and Romer, D. (1999). Does trade cause growth. American Economic Review, 89 (3), 379-399.

Greenaway, D, Leybourne, S. and Sapsford, D. (1997). Modeling growth and liberalisation using smooth transitions analysis. Economic Inquiry, 35 (4), 798-814.

Greenaway, D., Morgan, W. and Wright, P. (2002). Trade liberalisation and growth in developing countries. Journal of Development Economics, 67, 229-244.

Greenaway, D. and Sapsford, D. (1994). What does liberalization do for exports and growth. Weltwirtschaftliches Archiv, 130 (1), $152-174$.

Grossman, G. and Helpman, E. (1991). Innovation and growth in the global economy. Cambridge, MA: MIT Press.

Gül, E., Kamacı, A. ve Konya, S. (2013). Dış ticaretin büyüme üzerine etkileri: Türk Cumhuriyetleri ve Türkiye örneği. Akademik Bakış Dergisi, 35, 1-12.

Idris, J., Yusop, Z. and Habibullah, M. (2016). Trade openness and economic growth: a causality test in panel perspective. International Journal of Business and Society, 17 (2), 281-290.

Kaldor, N. (1970). The case for regional policies. Scottish Journal of Political Economy, 17 (3), 337-348.

Kılavuz, E. and Topçu, B. (2012). Export and economic growth in the case of the manufacturing industry: panel data analysis of developing countries. International Journal of Economics and Financial Issues, 2 (2), 201-215.

Korkmaz, S. ve Aydın, A. (2015). Türkiye'de dış ticaret-ekonomik büyüme ilişkisi: nedensellik analizi. Eskişehir Osmangazi Üniversitesi iißBF Dergisi, 10 (3), 47-76.

Krueger, A. (1978). Foreign trade regimes and economic development: liberalization attempts and consequences. Cambridge, MA: Ballinger. Levine, R. and Renelt, D. (1992). A sensitivity analysis of cross-country growth regressions. American Economic Review, 82 (4), $942-963$.

Lucas, R. (1988). On the mechanics of economic development. Journal of Monetary Economics, 22 (1), 3-42.

Majeed, M. (2010). Inequality, trade openness and economic growth in Asia. Applied Econometrics and International Development, 10 (2), 201-212.

Medina-Smith, Emilio J. (2001). Is the export-led growth hypothesis valid for developing countries? A case study of Costa Rica. United Nations Conference on Trade and Development, Policy Issues in International Trade and Commodities Study Series No. 7.

Mercan, M. ve Göçer, İ. (2014). Ticari dışa açıklığın ekonomik etkileri: Orta Asya ülkeleri için ampirik bir analiz. Uluslararası Yönetim İktisat ve Işletme Dergisi, 10 (22), 27-44.

Özcan, C., Özmen, İ. ve Özcan, G. (2018). Ticari dışa açıklık ve ekonomik büyüme arasındaki nedensellik ilişkisi: yükselen piyasa ekonomileri. Selçuk Üniversitesi Sosyal Bilimler Enstitüsü Dergisi, 40, 60-73.

Parida, P. and Sahoo, P. (2007). Export-led growth in South Asia: a panel cointegration analysis. International Economic Journal, 21 (2), 155175. 
Ram, R. (1985). Exports and economic growth: some additional evidence. Economic Development and Cultural Change, 33 (2), $415-425$.

Redding, S. (1999). Dynamic comparative advantage and the welfare effects of trade. Oxford Economic Papers, 51 (1), $15-39$.

Romer, P. (1986). Increasing returns and long-run growth. Journal of Political Economy, 94 (5), 1002-1037.

Saçık, S. (2009). Büyümenin bir kaynağı olarak ticari dışa açıklık. Sosyal Ekonomik Araştırmalar Dergisi, 9 (18), $273-294$.

Sağlam, Y. ve Egeli, H. (2015). İhracata dayalı büyüme hipotezi: Türkiye örneği. Dokuz Eylül Üniversitesi Sosyal Bilimler Enstitüsü Dergisi, 17 (4), 517-530.

Samman, E. (2005). Openness and growth: an empirical investigation. Human Development Report 2005, Occasional Paper: $2005 / 22$.

Santos-Paulino, A. and Thirlwall, A. (2004). The impact of trade liberalisation on exports, imports and the balance of payments of developing countries. Economic Journal, 114 (493), 50-72.

Silajdzic, S. and Mehic, E. (2017). Trade openness and economic growth: empirical evidence from transitions economies, Menagement International Conference, Italy, 24-27 May, 581-594.

Singer, H. and Gray, P. (1988). Trade policy and growth of developing countries: some new data. World Development, 16 (3), $395-403$.

Sprout, R. and Weaver, J. (1993). Exports and economic growth in a simultaneous equations model. Journal of Developing Areas, 27 (3), 289306.

Şerefli, M. (2016). Dış ticaretin ekonomik büyüme üzerine etkisi: Türkiye örneği. Kastamonu Üniversitesi iiBF Dergisi, 13 (5), $136-142$.

Tullock, G. (1967). The welfare costs of tariffs, monopolies and theft. Western Economic Journal, 5 (3), $224-232$.

Tunçsiper, B. ve Rençber, E. (2017). Dış ticaret ve ekonomik büyüme arasındaki nedensellik ilişkisi: Türkiye örneği. International Journal of Social Sciences and Education Research, 3 (2), 619-630.

Tupy, M. (2005). Trade liberalization and poverty reduction in Sub-Sahara Africa. Policy Analysis, No: 557, (https://object.cato.org/sites/cato.org/files/pubs/pdf/pa557.pdf (Erişim tarihi: 11.02.2019).

Türedi, S. ve Berber, M. (2010). Finansal kalkınma, ticari açıklık ve ekonomik büyüme arasındaki ilişki: Türkiye üzerine bir analiz. Erciyes Üniversitesi İtisadi ve Idari Bilimler Fakültesi Dergisi, 35, 301-316.

Ümit, Ö. (2016). Türkiye'de ticari açıklık, finansal açıklık ve ekonomik büyüme arasındaki ilişkiler: sınır testi yaklaşımı. Ömer Halisdemir Üniversitesi Iktisadi ve Idari Bilimler Fakültesi Dergisi, 9 (1), 255-272.

Vamvakidis, A. (2002). How robust is the growth-openness connection? Historical evidence. Journal of Economic Growth, 7 (1), 57-80.

Yanikkaya, H. (2003). Trade openness and economic growth: A cross-country empirical investigation. Journal of Development Economics, 72, 57-89.

Yapraklı, S. (2007). Ticari ve finansal dışa açıklık ile ekonomik büyüme arasındaki ilişki: Türkiye üzerine bir uygulama. İstanbul Üniversitesi iktisat Fakültesi Ekonometri ve Istatistik Dergisi, (5), 67-89.

Young, A. (1991). Learning by doing and the dynamic effects of international trade. The Quarterly Journal of Economics, 106 (2), $369-405$.

Yurdakul, F. and Aydın, M. (2018). Ekonomik büyüme ve dış ticaret arasındaki ilişki: Türkiye üzerine bir uygulama. Uluslararası iktisadi ve Idari incelemeler Dergisi, 18. EYi Özel Sayısı, 23-36.

Zahonogo, P. (2016). Trade and economic growth in developing countries: evidence from Sub-Saharan Africa. Journal of African Trade, 3 (12), 41-56. 